\title{
Pituitary Abscess
}

National Cancer Institute

\section{Source}

National Cancer Institute. Pituitary Abscess. NCl Thesaurus. Code C121148.

An inflammatory or infectious process in the pituitary gland characterized by a circumscribed, walled collection of purulent material. 